\title{
The Influence of SQ3R Technique and Students' Reading Interest towards Students' Reading Comprehension Achievement
}

\author{
Amiruddin \\ Universitas PGRI Palembang, Indonesia \\ e-mail: amiruddin@ univpgri-palembang.ac.id \\ Article History: Received on 10 November 2021, Revised on 30 January 2022 \\ Published on 10 February 2022
}

\begin{abstract}
This study was experimental research. The writer conducted this study at senior high school of SMK Negeri 3 Palembang. This study investigated to find out whether or not : (1) there is significant difference in reading comprehension achievement between the students who both have high reading interest taught by using SQ3R technique and those who are taught by using conventional technique, (2) there is significant difference in reading comprehension achievement between the students who both have low reading interest taught by using SQ3R technique and those who are taught by using conventional technique, (3) there is significant difference in reading comprehension achievement between the students who have high reading interest and low reading interest taught by using SQ3R technique, (4) there is significant difference in reading comprehension achievement between students who have high reading interest and low reading interest taught by using conventional strategy, (5) there is significant interaction effect of SQ3R strategy and reading interest towards the students' reading comprehension achievement. From the finding it was found that SQ3R contributed to improve students reading comprehension achievement.
\end{abstract}

Keywords: SQ3R, Reading Comprehension, Reading Interest

\section{A. Introduction}

Reading is one of language skills which should be mastered students in English learning process. Reading is similar to listening in which it is a receptive skill concerning with the ability to apprehend the meanings of the written or printed materials. Therefore, this skill needs to be developed for expanding knowledge of a language, such as vocabulary, grammar, form and meaning, sentence contraction, punctuation, and paragraph.

Through reading, students are not only finding the information of the text but also they learn how to structure sentences, how to select words and language effectively, how to arrange a good paragraph and comprehend the text which are absolutely needed to master language learning. Reading habits not only help the students get knowledge and wisdom from the cultural of heritage, but are also very helpful in passing for leisure period. It is a source of joys. Good reading is that which keeps students regular in reading which provide them both pleasure and profit. Furthermore, reading activity is one of the parts of language acquisition, if the reading text is especially interesting and engaging, acquisition will be more successful.

Reading is not a simple activity. According to Oakhill et al, (2015) there are several reasons why reading text is more difficult and more complex than understanding everyday spoken interactions or oral narratives. First, a text cannot be interrogated in the way that a partner in 
Volume 3 (1) 2022

E-ISSN: 2723-6919 P-ISSN:2746-0827

a conversation can be and it does not adapt in response to a puzzled look or indication of lack of comprehension by the listener. Second, a written text does not come with all the prosodic information that is so important for the understanding of spoken language, such as intonation patterns. In spoken language, a rising tone can indicate a question. A pause can indicate a change of subject or line of argument. The newcomer to written language has to learn to interpret the meanings of question marks and other punctuation, the significance of paragraphs, headlines, and references. Third, a written text is not everyday language. It is a more formal and complex form of language. Everyday spoken language does not typically contain embedded relative clauses and has simpler vocabulary. Fourth, written texts are much less anchored in the situation in which they are read than spoken dialogues are. In an oral discussion, words like here, over there, left, ahead, you, we, now, in a few minutes (deictic expressions) all make immediate sense because the speaker and the listener share the same situation or the same context for understanding. Part of the wonder of written texts is that they can convey meaning across time and distance in a way that spoken language often fails to do. Fifth, spoken messages are created on the fly and so are full of pauses, revisions, repetitions, and self interruptions. By contrast, written language is usually much denser. For fluent readers, written language carries much more information per word, and per unit of time. The risk is that some points will be lost, even when written language is read aloud slowly. For these reasons, teacher has to make reading easier and more interesting to help learners increase reading comprehension (Risdianto et al, 2020).

Students' interest in reading is another factor that can influence reading comprehension achievement. According to Tin (2016), interest is an important category of positive affect which promotes successful language learning and can help students to cope with a potentially threatening experience such as language learning where failures in language can cause embarrassment and harm their identity. Reading interest is the fundamental process for reading engagement and is major contributor, when things go away, to disengagement in reading.

Improvement of language skills, especially reading skill is a significant issue that all teachers need to be aware of in the English language teaching task. Based on the researcher's observation on senior high school of SMK Negeri 3 Palembang, it was found that many students get difficulty to find main idea, general and specific information, and to answer the given question of the written text. Furthermore, most of reading texts are hard for students when the texts are too long and had of a lot of unfamiliar words and complex sentence. It causes the students are less interest in reading the text. The writer was also found that the teacher often used reading aloud to teach reading comprehension. In other words, it can be concluded that students are not taught reading appropriately because the teacher only concern on how to read in good stress, intonation and pronunciation. Based on the description, the writer was interested to conduct a research entitled The Influence of SQ3R Technique and Students' Reading Interest towards Sudents' Reading Comprehension Achievement.

\section{B. Methods}

This study was conducted at the tenth grade students of SMK Negeri 3 Palembang. the writer used factorial design in experimental research. In this design, there were two groups, the first was the experimental group and the other was as control group. The total number of population were 157 students and the number of sample were 30 students with high reading interest and 30 students with low reading interest. All the data were collected by distributing 
Volume 3 (1) 2022

E-ISSN: 2723-6919 P-ISSN:2746-0827

questionnaire sheets, pretest and post test of reading comprehension for experimental group and control group.

\section{Results and Discussion}

On this investigation the writer used indepentent sample t-test and two way ANOVA to know the answer of the hypothesis. The hypothesis were; first, the students' ability in reading comprehension of pretest and posttest in the experimental group who have high reading interest. Second, the students' ability in reading comprehension of pretest and posttest in the experimental group who have low reading interest. Third, the students' ability in reading comprehension of students who have high and low reading interest in experimental group. Fourth, the students' ability in reading comprehension of students who have high and low reading interest in the control group. And the last, two way ANOVA used to know the interaction between SQ3R techique and students' reading interest toward reading comprehension.

\section{Measuring a significant Difference in Reading Comprehension between Students who Have High Reading interest Taught using SQ3R Technique and Conventional Technique}

There were fifteen students who had high reading interest in experimental group. Those students were taken into difference mean analysis with the fifteen students in control group who had high reading interest. The mean score of experimental group was 82.27 and 71.87 for control group. The standard deviations were 5.574 for experimental group and 6.163 for conrol group.

From the statistical calculation using independent sampled t-test, it was found that the poutput or sig. (2 tailed) value was 0.000 with degree of freedom 28 and significance level 0.05 . Since the value of sig. ( 2 tailed) was smaller than 0.05 , it meant that the students who have high reading interest thaugh by using SQ3R technique and conventional technique were significantly different. In other word, there was significant difference in reading comprehension between students who have high reading interest thaught using SQ3R technique and conventional technique.

Measuring a significant Difference in Reading Comprehension between Students who Have Low Reading interest Taught using SQ3R Technique and Conventional Technique

There were fifteen students who had low reading interest in experimental group. Those students were taken into difference mean analysis with the fifteen students in control group who had low reading interest. The mean score of experimental group was 72.13 and 57.40 for control group. The standard deviations were 6.958 for experimental group and 11.375 for conrol group.

From the statistical calculation using independent sampled t-test, it was found that the poutput or sig. ( 2 tailed) value was 0.000 with degree of freedom 28 and significance level 0.05 . Since the value of sig. ( 2 tailed) was smaller than 0.05 , it meant that the students who have low reading interest thaugh by using SQ3R technique and conventional technique were significantly different. In other word, there was significant difference in reading 
Volume 3 (1) 2022

E-ISSN: 2723-6919 P-ISSN:2746-0827

comprehension between students who have low reading interest thaught using SQ3R technique and conventional technique.

\section{Measuring a significant Difference in Reading Comprehension between Students who Have High and Low Reading interest Taught using SQ3R Technique}

There were fifteen students who had high reading interest thaught using SQ3R Technique. Those students were taken into difference mean analysis with the fifteen students who had low reading interest thaught using SQ3R technique. The mean score of students who had high reading interest thaught using SQ3R technique was 82.27 and 72.13 for students who had high reading interest thaught using SQ3R technique. The standard deviations were 5.574 for students who had high reading interest thaught using SQ3R and 6.958 for students who had low reading interest thaught using SQ3R.

From the statistical calculation using independent sampled t-test, it was found that the poutput or sig. ( 2 tailed) value was 0.000 with degree of freedom 28 and significance level 0.05 . Since the value of sig. ( 2 tailed) was smaller than 0.05 , it meant that the students who have high and low reading interest thaugh by using SQ3R technique were significantly different. In other word, there was significant difference in reading comprehension between students who have high and low reading interest thaught using SQ3R technique.

\section{Measuring a significant Difference in Reading Comprehension between Students who Have High and Low Reading interest Taught using Conventional Technique}

There were fifteen students who had high reading interest thaught using Conventional Technique. Those students were taken into difference mean analysis with the fifteen students who had low reading interest thaught using Conventional technique. The mean score of students who had high reading interest thaught using Conventional technique was 72.40 and 57.33 for students who had low reading interest thaught using Conventional technique. The standard deviations were 6.770 for students who had high reading interest thaught using Conventional and 11.629 for students who had low reading interest thaught using Conventional.

From the statistical calculation using independent sampled t-test, it was found that the poutput or sig. ( 2 tailed) value was 0.000 with degree of freedom 28 and significance level 0.05 . Since the value of sig. ( 2 tailed) was smaller than 0.05 , it meant that the ability of students who have high and low reading interest thaugh by using conventional technique were significantly different. In other word, there was significant difference in reading comprehension between students who have high and low reading interest thaught using conventional technique.

\section{Measuring an Interaction Effect between SQ3R Technique and Students' Reading Interest towards Students' Reading Comprehension}

In the statistical analyses, the writer applied two-way ANOVA which was concern with the investigation of the relationship between one dependent variable (reading achievement) and two or more variables (SQ3R Technique and Reading Interest). From the descriptive statistics of Two-Way ANOVA, it was found that the students who had high reading interest and were taught by using SQ3R technique achieved the higher mean score (82.27). It meant that SQ3R 
technique was mostly effective used in teaching reading ability to students who had high reading interest.

Furthermore, it was necessary to check whether or not the interaction significant by checking the significant value. If the value is less than or equal to 0.05 , then there is a significant interaction. From the calculation analysis, it was found that the significance value was 0.290. It was higher than significance level 0.05 . This finding indicated that there was no interaction effect of SQ3R technique and students' reading interest toward students' reading comprehension achievement.

\section{SQ3R}

Teacher can help learners increase reading comprehension in number of different ways. One of considerable important ways is determining technique or strategy used in teaching and learning process. SQ3R is an active reading technique that can be used to improve student interest and achievement. This technique is introduced by Francis Pleasant Robinson, an American education philosopher in his book entitled "Effective Study" in 1966. He claimed that this technique is more efficient and active approach for college students to reading textbook material. In applying this technique, the teacher teaches students with five steps, they are survey, question, read, recite and review the text given. This technique may appropriate for students because they are given a chance to be active in teaching learning process (Biringkanae, 2018).

The term of SQ3R technique is defined in several ways by experts. According to Manktelow (2003) SQ3R is a useful technique for fully absorbing written information. SQ3R helps students create a good mental framework of a subject, into which they can fit facts correctly. It helps students set study goals. It also prompts students to use the review techniques that will help fix information in their mind (Kusumayanthi \& Maulidi, 2019; Kasmawati \& Sakkir, 2020).

Richards (2002) state that SQ3R is an acronym for Survey, Question, Read, Recite and Review. It is a reading strategy for students who are reading for study purposes. Meanwhile, Brown (2002) claimed that SQ3R technique is one of effective series of procedures for approaching a reading text. It serves as general guide for a reading class (Pokharel et al, 2021).

There have been some reseachers conducted research about SQ3R. Biringkanae (2018) reported that SQ3R contributes as the technique to help the teacher convey the material easily and makes the students easy in receiving the material too. SQ3R is a useful technique for fully absorbing written information. It helps the students to create a good metal framework of a subject, into which the reader can fit fact correctly. SQ3R technique helps the students to set study goals. It also prompts the students to use the review techniques that will helps to fix information in their mind. Aziz (2020) found that can improve skills in reading students' English texts. In addition Kasmawati and Sakir (2020) also found that improved learning process is shown by students more active and enthusiastic following the learning process implementing the SQ3R strategy.

SQ3R is an active reading technique that can be used to improve student's interest and achievement in reading. This technique enables students to be active in teaching and learning. SQ3R stand for the following five steps: 


\section{a. Survey}

Surveying is the first stage in SQ3R technique. The term of survey means the process of rapid reading which is used to get an overview of the text. Students look through the title, preview or introduction, heading or subheadings and summaries to get an overall idea of what the text might contain. Moreover, this orientation will help students organize the ideas.

\section{b. Question}

After the readers have surveyed the text, the students make questions from the heading. This will arouse curiosity and so increase comprehension. It will bring to mind information already known, thus helping students to understand that section more quickly. Understanding the answers can help students structure the information in mind.

\section{c. Read}

In this step, the students read all the text in detail and take care to understand all the points that are relevant to the answers of the previous formulated question. In the case of some texts this reading may be very slow. This will particularly be the case if there is a lot of dense and complicated information.

\section{d. Recite}

The fourth step is reciting. It means the readers answer all of the questions by using their own words and examples. The readers can write down cue phrase in outline form on a sheet of paper. Furthermore, the readers underline the important points, and then the readers are asked to recall or recite all the materials that have been studied.

\section{e. Review}

The last step is reviewing. In this step, the readers have to review the exercise by recalling the main points and discussing it together. Then expose each major point and try to recall the sub points listed under it. The review will help the readers memorize material as it prepares for exam.

\section{Conclusion}

Based on the result of this research it could be interpreted that SQ3R technique contributed to improve students' reading comprehension achievement. It can be seen from the student's posttest score in experimental group, the students who had high and low reading interest had a better score in reading comprehension than the students in control group. The writer would like to offer some suggestions that the teachers should explore the kinds of teaching technique to improve students reading comprehension and should be creative in making the class alive and interesting in order to stimulate and increase their interest.

\section{E. Acknowledgement}

I thank to Rector Universitas PGRI Palembang, Principal SMK Negeri 3 Palembang, and friends in FKIP Universitas PGRI Palembang who have supported me to do this valuable project.

\section{References}


Volume 3 (1) 2022

E-ISSN: 2723-6919 P-ISSN:2746-0827

Amelia, B. (2018). The Use of SQ3r Technique in Improving Students Reading Comprehension. ELS Journal on Interdisciplinary Studies on Humanities, 1(2), 218225.

Biringkanae, A. (2018). The use of SQ3R technique in improving studentsreading comprehension. ELS Journal on Interdisciplinary Studies in Humanities, 1(2), 218-225.

Brown, H. (1995). Teaching by Principles: an Interactive Approach to Language Pedagogy. New Jersey: Englewood Cliffs, NJ: Prentice Hall Regents.

Kasmawati, S. (2020). Improving Students Reading Comprehension Through "Survey, Question, Reading, Recite, Review (SQ3R) Strategy. Journal of Language, Literature, and linguistics, 92-99.

Kasmawati, K., \& Sakkir, G. (2020). Improving students reading comprehension through "survey, question, reading, recite, review (SQ3R)" STRATEGY. Interference: Journal of Language, Literature, and Linguistics, 1(2), 92-99.

Kusumayanthi, S., \& Maulidi, S. M. (2019). The implementation of SQ3R Technique in teaching reading comprehension. JELA (Journal of English Language Teaching, Literature and Applied Linguistics), 1(2), 74-80.

Manktelow, J. ( 2003). Mind Tool, Essential Skill. UK: Signal House.

Nur, A. I. (2020). Implementation Of SQ3R Method In Improving The Students' Basic Reading Skill. EDUCATIO: Journal Of Education, 5(1), 97-106.

Oakhill, J. C. (2015). Understanding and Teaching Reading Comprehension. New York: Routledge.

Pokharel, M., \& Sharma, M. R. (2021). Classroom Management: Glocalized Contexts. Journal of Social Work and Science Education, 2(1), 11-20. https://doi.org/10.52690/jswse.v2i1.136

Richard (1985). Readibility of Test. Canada: Nelson.

Risdianto, E., Fitria, J., Johan, H., \& Macariola, J. S. (2020). Teacher's Perception of Thermodynamic Law Module Developed in Training through Student's Critical Thinking Skills. Journal of Social Work and Science Education, 1(1), 78-86. https://doi.org/10.52690/jswse.v1i1.19

Robinson, F. (1961). Effective Study. USA: Harper and Row.

Tin, B. T. (2016). Stimulating Student Interest in Language Learning, Theory Research and Practice. London: Macmillan Publishers Ltd. 